\title{
Native Wildflower Establishment with Imidazolinone Herbicides
}

\author{
Daniel D. Beran ${ }^{1}$ \\ Department of Agronomy, University of Nebraska, Lincoln, NE 68583-0915 \\ Roch E. Gaussoin ${ }^{2}$ \\ Department of Horticulture, University of Nebraska, Lincoln, NE 68583-0724
}

\author{
Robert A. Masters ${ }^{3}$ \\ U.S. Department of Agriculture, Agricultural Research Service, Lincoln, \\ NE 68583-0915
}

\begin{abstract}
Additional index words. blackeyed susan (Rudbeckia hirta), blanket flower (Gaillardia aristata), upright prairieconeflower (Ratibida columnifera), spiked liatris (Liatris spicata), purple coneflower (Echinacea purpurea), spotted beebalm (Monarda punctata), imazapic, imazaquin, imazethapyr
\end{abstract}

\begin{abstract}
Native wildflowers are important components of grassland communities and low-maintenance wildflower seed mixtures. Weed interference limits successful establishment of native wildflowers from seed. Experiments were conducted to determine the influence of the imidazolinone herbicides imazethapyr, imazapic, and imazaquin on the establishment of blackeyed susan (Rudbeckia hirta L.), upright prairieconeflower [Ratibida columnifera (Nutt) Woot. and Standl.], spiked liatris [Liatris spicata (L.) Willd.], blanket flower (Gaillardia aristata Pursh.), purple coneflower [Echinacea purpurea (L.) Moench.], and spotted beebalm (Monarda punctata L.). Wildflower response to the herbicide treatments was variable and appeared to be influenced by the level of weed interference. Establishment of the native wildflowers after application of imazethapyr or imazapic at 70 $\mathrm{g} \cdot \mathrm{ha}^{-1} \mathbf{a}$.i. was generally improved at sites with greater weed interference. Emergence and density of wildflowers was often reduced by imazapic in sites with low weed interference. Flower density during the second growing season was usually either improved or not reduced by either imazethapyr or imazapic. Based on these findings, imazethapyr and imazapic can reduce weed interference and improve the establishment of some native wildflowers in areas with high weed infestations. Chemical names used: $( \pm)-2-[4,5-$ dihydro-4-methyl-4-(1-methylethyl)-5-oxo-1H-imidazol-2-yl]-5-methyl-3pyridinecarboxylic acid (imazapic); 2-[4,5-dihydro-4-methyl-4-(1-methylethyl)-5-oxo-1Himidazol-2-yl]-3-quinolinecarboxylic acid (imazaquin); 2-[4,5-dihydro-4-methyl-4-(1methylethyl)-5-oxo-1H-imidazol-2-yl]-5-ethyl-3-pyridinecarboxylic acid (imazethapyr).
\end{abstract}

Prairie ecosystems of the Great Plains were once among the most floristically diverse plant communities in North America (Jordan et al., 1988). Weaver (1954) recorded more than 200 species in the tallgrass prairie with the majority being forbs or wildflowers. Native wildflowers are an essential segment of prairie communities and are used for a variety of purposes. Wildflower mixtures containing

\footnotetext{
Received for publication on 3 Apr. 1998. Accepted for publication 1 Aug. 1998. Contribution Number 12180 of the Nebraska Agricultural Research Div. and the U.S. Dept. of Agriculture-Agricultural Research Service (USDA-ARS). The authors wish to thank Kevin Grams, Leonard Wit, Fernando RivasPantoja, Brenda Younkin, and LeAnn Beran for their assistance, and the Arthur Sampson Endowment Fund, American Cyanamid, and the Nebraska Turf Foundation for partial support. Mention of trade names or pesticides does not imply recommendation by the Univ. of Nebraska-Lincoln or USDAARS, nor does it imply registration under FIFRA. The cost of publishing this paper was defrayed in part by the payment of page charges. Under postal regulations, this paper must therefore be marked advertisement solely to indicate this fact.

${ }^{1}$ Research Assistant.

${ }^{2}$ Associate Professor.

${ }^{3}$ Rangeland Scientist.
}

have potential for improving grass establishment, their utility in establishing wildflowers is limited. Bragg and Sutherland (1989) reported greater wildflower establishment following mowing than following applications of atrazine or 2,4-D when wildflowers and grasses were seeded together. Recent findings by Masters et al. (1996) provide evidence that the imidazolinone herbicides imazethapyr and imazapic can improve the establishment of several native warm-season grasses, including big bluestem (Andropogon gerardii Vitman var. gerardii), indiangrass [Sorghastrum nutans (L.) Nash ex Small], and little bluestem [Schizachyrium scoparium (Michx.) Nash], as well as selected native legumes and asters.

The imidazolinone herbicides control a wide range of broadleaf and grassy weeds and possess both foliar and soil activity (Little and Shaner, 1991; Shaner and Mallipudi, 1991). By identifying wildflowers that are tolerant to imidazolinone herbicides, an important weed control option could be developed that would reduce weed interference and improve the reliability of wildflower establishment. The imidazolinone herbicides have the potential to be versatile weed management options that could enable establishment of diverse mixtures of tolerant wildflowers and native grasses. This research was conducted to determine the influence of imidazolinone herbicides on emergence, density, and flowering of native wildflowers.

\section{Materials and Methods}

Four experiments were initiated from 1994 to 1996 at the John Seaton Anderson Turfgrass and Ornamental Research Facility near Mead, Nebr. Soil at all sites was a Sharpsburg silty clay loam (fine, smectitic, mesic Typic Argiudoll). Experiments were designed as randomized complete blocks with four replications in the 1994 and 1996 experiments, and three replications in the 1995 experiment.

1994 experiments. Two experiments were conducted in 1994, one on an irrigated site and the other on a nonirrigated site; both had previously been maintained as tall fescue (Festuca arundinacea Schreb.) sod. The irrigated site received a minimum of $2.5 \mathrm{~cm}$ of water each week by irrigation and/or rainfall. Sites were tilled and cultipacked to provide a clean seedbed for planting. A 60-cm-wide border of Kentucky bluegrass (Poa pratensis L.) sod was planted around each $1 \times 2-m$ plot. Within each plot, a single species was seeded to a maximum depth of $1.2 \mathrm{~cm}$ into three rows that were $20 \mathrm{~cm}$ apart. Pure live seed (PLS) of blackeyed susan $\left(2.3 \mathrm{~kg} \cdot \mathrm{ha}^{-1}, 810 \mathrm{PLS} / \mathrm{m}^{2}\right)$, spiked liatris $\left(9.3 \mathrm{~kg} \cdot \mathrm{ha}^{-1}, 260 \mathrm{PLS} / \mathrm{m}^{2}\right)$, and upright prairieconeflower $\left(2.1 \mathrm{~kg} \cdot \mathrm{ha}^{-1}, 270\right.$ PLS $/ \mathrm{m}^{2}$ ) were planted at both sites on 8 June 1994.

Herbicide treatments were applied to individual plots on 10 June 1994. The herbicide treatments were no herbicide and imazethapyr or imazapic applied at $70 \mathrm{~g} \cdot \mathrm{ha}^{-1}$. Methylated seed oil (SUNIT II; Agsco, Grand Forks, N.D.) and $28 \%$ urea ammonium nitrate at $1.25 \% \mathrm{v} / \mathrm{v}$ were added to the spray solution as adjuvants. 
Herbicides were applied with a backpack sprayer that delivered $163 \mathrm{~mL} \cdot \mathrm{m}^{-2}$ at $240 \mathrm{kPa}$. The dominant weed species at both sites were smooth crabgrass [Digitaria ischaemum (Schreb. ex. Schweig) Schreb. ex Muhl.] and redroot pigweed (Amaranthus retroflexus L.).

1995 experiment. In 1995, an experiment was initiated on an irrigated site that had previously been maintained as a low-maintenance Kentucky bluegrass sod. Site preparation, plot size, planting method, and irrigation method were similar to those in the 1994 irrigated experiment. Blackeyed susan, upright prairieconeflower, blanket flower, purple coneflower, and spotted beebalm were seeded at $300 \mathrm{PLS} / \mathrm{m}^{2}$ on 28 June 1995 . The planting date was delayed and relatively late because of excessive rainfall during May and June 1995. Herbicide treatments were applied to individual plots on 29 June 1995. Treatments were no herbicide and imazapic, imazethapyr, or imazaquin applied at $70 \mathrm{~g} \cdot \mathrm{ha}^{-1}$. Methylated seed oil and $28 \%$ urea ammonium nitrate were added to the spray solution and applied at 380 $\mathrm{mL} \cdot \mathrm{ha}^{-1}$. The primary weed species present at the site were swamp smartweed (Polygonum coccineum Muhl. ex Willd.), horseweed [Conyza canadensis (L.) Cronq.], large crabgrass [Digitaria sanguinalis (L.) Scop.], and smooth crabgrass.

1996 experiment. In 1996, an experiment was initiated on an irrigated site that had previously been maintained as a tall fescue sod. Site preparation, plot size, planting method, and irrigation method were similar to those in the 1995 experiment. Blanket flower and purple coneflower were seeded at 300 $\mathrm{PLS} / \mathrm{m}^{2}$ on 19 May 1996. Herbicide treatments were no herbicide and imazethapyr and imazapic applied at $70 \mathrm{~g} \cdot \mathrm{ha}^{-1}$, and were applied on 20 May 1996. Dominant weeds at the site were common lambsquarters (Chenopodium album L.), redroot pigweed, and smooth crabgrass.

For all experiments, weed control and planted species emergence were recorded 4 weeks after herbicide treatment. These variables were expressed as percentages on a $0 \%$ to $100 \%$ scale, with 0 representing no weed control or no emergence and 100 representing complete weed control or complete emergence.

Stand establishment was assessed 1 year after planting. To reduce growth of annual grasses that would have interfered with sampling during the second growing season, a uniform application of fluazifop-P-butyl [butyl $+R-2-[4-[[5-($ trifluoromethyl)-2pyridinyl]oxy]phenoxy]propionate] was applied to all plot areas at $0.4 \mathrm{~kg} \cdot \mathrm{ha}^{-1}$ with a backpack sprayer once annual grasses had reached a height of $2.5 \mathrm{~cm}$ (June). Fourteen months after planting (August-September), plant and flower density of the planted wildflowers were recorded. Plant density was determined by placing a $0.5-\mathrm{m}^{2}$ quadrat across the three rows of each plot and counting the number of individual plants or rosettes rooted within the quadrat. Plant density of spotted beebalm was not recorded because individual plants were indistinguishable. Flower density of blackeyed susan, upright prairieconeflower, blanket flower, and purple coneflower was determined by counting the number of composite flower heads arising from rooted plants within the quadrat, that of spiked liatris and spotted beebalm by counting the number of flowering stems rooted within the quadrat.

Due to different seeding rates within species and the inclusion of imazaquin in 1995, each year's experiments were analyzed separately. Data from the irrigated and nonirrigated sites in 1994 were also analyzed separately and homogeneity of error variances tested with Hartley's F-max test (Hartley, 1950) prior to pooling of the data. Within all experiments weed control data were combined across wildflower species while the other variables were analyzed within species. Arcsin transformation (Lentner and Bishop, 1993) was performed on the percentage weed control and emergence data. Nontransformed data are presented because the results for transformed and nontransformed data were similar. Means of the response variables were separated with Fisher's protected LSD $(P \leq 0.05)$.

Table 1. Weed control based on visual ratings 4 weeks after treatment with imidazolinone herbicides at sites near Mead, Nebr. All herbicides were applied at $70 \mathrm{~g} \cdot \mathrm{ha}^{-1}$ a.i.

\begin{tabular}{lccr}
\hline \hline & \multicolumn{3}{c}{ Weed control (\%) } \\
\cline { 2 - 4 } Herbicide & $1994^{\mathrm{z}}$ & $1995^{\mathrm{y}}$ & $1996^{\mathrm{x}}$ \\
\hline Imazapic & 96 & 94 & 100 \\
Imazethapyr & 68 & 95 & 96 \\
Imazaquin & --- & 78 & --- \\
Nontreated & 0 & 0 & 0 \\
$\mathrm{LSD}_{0.05}$ & 5 & 6 & 5
\end{tabular}

${ }^{2}$ Means averaged across irrigated and nonirrigated sites; dominant weed species were smooth crabgrass and redroot pigweed.

${ }^{y}$ Dominant weed species were smooth crabgrass, large crabgrass, marestail, and swamp smartweed.

${ }^{x}$ Dominant weed species were smooth crabgrass, redroot pigweed, and common lambsquarters.

Table 2 . Native wildflower emergence 4 weeks after sowing seed, and plant and flower density $\approx 14$ months after sowing from experiments initiated in 1994 at irrigated (IR) and nonirrigated (NIR) sites near Mead, Nebr. Both herbicides were applied at $70 \mathrm{~g} \cdot \mathrm{ha}^{-1} \mathrm{a}$.i.

\begin{tabular}{|c|c|c|c|c|c|}
\hline \multirow[b]{2}{*}{ Herbicide } & \multicolumn{5}{|c|}{ Species } \\
\hline & \multicolumn{2}{|c|}{ Blackeyed susan $^{2}$} & \multicolumn{2}{|c|}{ Spiked liatris ${ }^{y}$} & $\begin{array}{l}\text { Upright prairie- } \\
\text { coneflower }^{\mathrm{x}}\end{array}$ \\
\hline & \multicolumn{5}{|c|}{ Emergence (\%) } \\
\hline & $\underline{\mathrm{IR}}$ & $\underline{\text { NIR }}$ & & & \\
\hline Imazapic & 6 & 1 & & & 1 \\
\hline Imazethapyr & 26 & 6 & & & 5 \\
\hline Nontreated & 0 & 1 & & & 0 \\
\hline \multirow[t]{3}{*}{$\mathrm{LSD}_{0.05}$} & 7 & 7 & & & 4 \\
\hline & \multicolumn{5}{|c|}{ Plant density $\left(\right.$ no. $\left./ \mathrm{m}^{2}\right)$} \\
\hline & & & $\underline{\mathrm{IR}}$ & NIR & \\
\hline Imazapic & & & 9 & 1 & 5 \\
\hline Imazethapyr & & & 12 & 1 & 5 \\
\hline Nontreated & & & 0 & 0 & 3 \\
\hline \multirow[t]{3}{*}{$\mathrm{LSD}_{0.05}$} & & & 7 & NS & NS \\
\hline & \multicolumn{5}{|c|}{ Flower density $\left(\right.$ no. $\left./ m^{2}\right)$} \\
\hline & & & $\underline{\mathrm{IR}}$ & NIR & \\
\hline Imazapic & \multicolumn{2}{|c|}{178} & 4 & 0 & 700 \\
\hline Imazethapyr & \multirow{2}{*}{\multicolumn{2}{|c|}{$\begin{array}{r}235 \\
75\end{array}$}} & 5 & 0 & 1099 \\
\hline Nontreated & & & 0 & 0 & 358 \\
\hline $\mathrm{LSD}_{0.05}$ & \multicolumn{2}{|c|}{ NS } & 3 & NS & NS \\
\hline
\end{tabular}

${ }^{2}$ Emergence data for blackeyed susan from both irrigated (IR) and nonirrigated (NIR) sites are presented because of a significant herbicide $\times$ site interaction.

yPlant and flower density from irrigated and nonirrigated sites were analyzed separately due to nonhomogenous error variances.

${ }^{x}$ Data averaged across irrigated and nonirrigated sites.

Nonsignificant at $P \leq 0.05$. 
imazethapyr-treated plots than in imazapictreated and nontreated plots.

Fourteen months after planting, plant density of blackeyed susan was higher in herbicide-treated areas than in nontreated areas, but flower density was not affected (Table 2). Spiked liatris plant and flowering stem density were both improved by applications of imazethapyr or imazapic, but only in the irrigated site. Lack of moisture in the nonirrigated site appeared to limit the survival and establishment of spiked liatris. When data were averaged across irrigated and nonirrigated sites, imazethapyr increased emergence of upright prairieconeflower, but effects of the herbicides on plant and flower density were nonsignificant.

1995 experiment. Imazapic and imazethapyr provided greater control of crabgrass and marestail than did imazaquin 4 weeks after treatment (Table 1). Weed interference was lighter ( $<25 \%$ canopy cover) than that in the 1994 experiments, probably because of the late seedbed preparation and planting (28 June). The lack of weed interference resulted in $>50 \%$ emergence ratings for blackeyed susan, upright prairieconeflower, blanket flower, and purple coneflower in the nontreated plots (Table $3)$. Treatment with imazethapyr, imazapic, or imazaquin reduced emergence of blackeyed susan and upright prairieconeflower. Injury symptoms for these species after emergence included seedling chlorosis, purpling, and stunting. Emergence of blanket flower and purple coneflower was $>55 \%$ in all treatments and was not significantly affected by herbicide treatment. No spotted beebalm plants were observed in plots treated with imazapic or imazethapyr 4 weeks after planting, but variability was great and the differences between treatments were not significant. Plant density of blackeyed susan, upright prairieconeflower, blanket flower, and purple coneflower was greatest in the nontreated areas (Table 3). However, only blackeyed susan flower density differences were significant, with imazapic and imazaquin treatments reducing flowering.

1996 experiment. Four weeks after application, both imazethapyr and imazapic provided $>95 \%$ weed control (Table 1). Emergence of blanket flower was reduced by imazapic treatment, whereas that of purple coneflower was not (Table 4). Weed interference was low ( $<25 \%$ canopy cover) during this period but increased toward the end of the first growing season. Neither plant nor flower density of blanket flower and purple coneflower in 1997 was reduced by herbicide treatment (Table 4).

Imazethapyr and imazapic provided similar weed control 1 month after planting at two of the four sites. In 1994, imazapic provided superior weed control at sites where there was severe interference from smooth crabgrass. Imazethapyr and imazapic were least injurious and most beneficial in these environments. In the 1994 experiments, establishment of blackeyed susan and upright prairieconeflower was either improved or not reduced by treatment with imazethapyr or imazapic, as indi-

Table 3. Native wildflower emergence 4 weeks after sowing seed, and plant and flower density $\approx 14$ months after sowing from an experiment initiated in 1995 at an irrigated site near Mead, Nebr. All herbicides were applied at $70 \mathrm{~g} \cdot \mathrm{ha}^{-1}$ a.i.

\begin{tabular}{|c|c|c|c|c|c|}
\hline \multirow[b]{2}{*}{ Herbicide } & \multicolumn{5}{|c|}{ Species } \\
\hline & $\begin{array}{l}\text { Blackeyed } \\
\text { susan }\end{array}$ & $\begin{array}{l}\text { Upright prairie- } \\
\text { coneflower }\end{array}$ & $\begin{array}{l}\text { Blanket } \\
\text { flower }\end{array}$ & $\begin{array}{c}\text { Purple } \\
\text { coneflower }\end{array}$ & $\begin{array}{c}\text { Spotted } \\
\text { beebalm }\end{array}$ \\
\hline & \multicolumn{5}{|c|}{ Emergence (\%) } \\
\hline Imazapic & 0 & 3 & 58 & 57 & 0 \\
\hline Imazethapyr & 18 & 17 & 63 & 68 & 0 \\
\hline Imazaquin & 3 & 20 & 62 & 60 & 27 \\
\hline Nontreated & 73 & 57 & 85 & 65 & 35 \\
\hline \multirow[t]{2}{*}{$\mathrm{LSD}_{0.05}$} & 20 & 22 & NS & NS & NS \\
\hline & \multicolumn{5}{|c|}{ Plant density $\left(\right.$ no. $\left./ \mathrm{m}^{2}\right)$} \\
\hline Imazapic & 1 & 4 & 11 & 4 & --- \\
\hline Imazethapyr & 15 & 8 & 25 & 10 & --- \\
\hline Imazaquin & 4 & 8 & 13 & 11 & --- \\
\hline Nontreated & 46 & 17 & 36 & 28 & --- \\
\hline \multirow[t]{2}{*}{$\mathrm{LSD}_{0.05}$} & 18 & 6 & 16 & 9 & \\
\hline & \multicolumn{5}{|c|}{ Flower density $\left(\right.$ no. $\left./ m^{2}\right)$} \\
\hline Imazapic & 52 & 1167 & 17 & 1 & 14 \\
\hline Imazethapyr & 525 & 1096 & 27 & 9 & 17 \\
\hline Imazaquin & 135 & 842 & 11 & 2 & 91 \\
\hline Nontreated & 708 & 1030 & 36 & 6 & 126 \\
\hline $\mathrm{LSD}_{0.05}$ & 310 & NS & NS & NS & NS \\
\hline
\end{tabular}

${ }^{2}$ Plant density data were not collected for spotted beebalm.

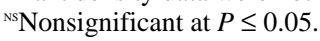

Table 4. Native wildflower emergence 4 weeks after sowing seed, and plant and flower density $\approx 14$ months after sowing from an experiment initiated in 1996 at an irrigated site near Mead, Nebr. Both herbicides were applied at $70 \mathrm{~g} \cdot \mathrm{ha}^{-1}$.

\begin{tabular}{|c|c|c|}
\hline \multirow[b]{2}{*}{ Herbicide } & \multicolumn{2}{|c|}{ Species } \\
\hline & Blanket flower & Purple coneflower \\
\hline & \multicolumn{2}{|c|}{ Emergence (\%) } \\
\hline Imazapic & 15 & 23 \\
\hline Imazethapyr & 43 & 38 \\
\hline Nontreated & 58 & 37 \\
\hline \multirow[t]{2}{*}{$\mathrm{LSD}_{0.05}$} & 27 & NS \\
\hline & \multicolumn{2}{|c|}{ Plant density $\left(\right.$ no. $\left./ m^{2}\right)$} \\
\hline Imazapic & 20 & 10 \\
\hline Imazethapyr & 26 & 19 \\
\hline Nontreated & 15 & 9 \\
\hline \multirow[t]{2}{*}{$\mathrm{LSD}_{0.05}$} & NS & NS \\
\hline & \multicolumn{2}{|c|}{ Flower density $\left(\right.$ no. $\left./ m^{2}\right)$} \\
\hline Imazapic & 430 & 84 \\
\hline Imazethapyr & 428 & 114 \\
\hline Nontreated & 106 & 22 \\
\hline $\mathrm{LSD}_{0.05}$ & NS & NS \\
\hline
\end{tabular}

${ }^{\text {Ns Nonsignificant at } P \leq 0.05}$

cated by emergence, plant density, and flower density. In contrast, the herbicide treatments reduced emergence and plant density of blackeyed susan and upright prairieconeflower in the 1995 site, which had lower weed pressure and a later planting date. Native grass establishment studies conducted in eastern Nebraska and Kansas have indicated that activity of the imidazolinone herbicides may be greater in areas with less weed competition. Imazapyr [( \pm )-2-[4,5-dihydro-4-methyl-4-(1methylethyl)-5-oxo-1 $H$-imidazol-2-yl]-3pyridinecarboxylic acid] improved stand establishment of switchgrass (Panicum virgatum L.) at a site with severe annual grass pressure, but reduced establishment at a site with low weed pressure (Masters et al., 1996). Likewise, seedling buffalograss [Buchloe dactyloides (Nutt.) Engelm.] injury from imazapic was greater at sites where weed infestations were low or moderate (Fry et al., 1997). Thus, in this region, the rates of these herbicides, particularly imazapic, could likely be reduced in areas of lower weed competition to reduce the risk of injury to seeded wildflowers.

Flowering density was variable and few effects of herbicides were detected. When plant density was reduced by the herbicide treatments, as in upright prairieconeflower in 1995, the surviving plants were able to grow in a less competitive environment and the resulting flowering density was similar to that in nontreated areas. Thus, the impacts of initial injury and stand reduction may be overcome by increased growth, flowering, and seed production of the remaining wildflowers.

This study provides evidence that imidazolinone herbicides are a promising weed management option for establishing certain native forbs and wildflowers. Blackeyed susan, upright prairieconeflower, and spiked liatris establishment was not reduced when treated with imidazolinone herbicides in weedy sites, nor was flowering of upright prairieconeflower, blanket flower, and purple coneflower adversely affected by the imidazolinone herbicides used in this study. When establishing 
native wildflowers, the primary benefit of these herbicides is the reduction of weed interference in sites with significant weed competition, particularly from annual grasses.

Of the herbicides evaluated in this study, only imazapic is labeled for the establishment of certain wildflowers. The current label indicates that stand thinning and injury to wildflowers from imazapic may occur because of genetic variation within wildflower species and environmental conditions. Additionally, the label recommends that imazapic be used for establishing labeled wildflowers when they are seeded in mixtures with tolerant grasses.

A promising aspect of the imidazolinone herbicides is the tolerance exhibited by several native warm-season grasses, such as big bluestem, little bluestem, and indiangrass (Masters et al., 1996), that are often seeded in mixtures with native forbs and wildflowers. Seed mixtures containing native grasses and wildflowers are used extensively in roadsides, parks, golf course roughs, wildlife habitat plantings, and prairie restoration projects. The imidazolinone herbicides have the potential to be a valuable weed control option for establishment of diverse mixtures of grasses and wildflowers in these areas.

\section{Literature Cited}

Bragg, T.B. and D.M. Sutherland. 1989. Establishing warm-season grasses and forbs using herbicides and mowing, p. 81-89. In: T.B. Bragg and J. Stubbendieck (eds.). Proc. 11th North Amer. Prairie Conf., Lincoln, Nebr.

Cox, M.L. and M.K. McCarty. 1958. Some factors affecting establishment of desirable forage plants in weedy bluegrass pastures of eastern Nebraska. J. Range Mgt. 11:159-164.

Dickens, R. 1992. Wildflower weed control. Grounds Maintenance. April. p. 66-72.

Fry, J.D., R.E. Gaussoin, D.D. Beran, and R.A. Masters. 1997. Buffalograss establishment with preemergence herbicides. HortScience 32:683-686.

Hartley, H.O. 1950. The maximum $F$-ratio as a short-cut test for heterogeneity of variance. Biometrika 37:308-312.

Howell, E.A. and V.M. Kline. 1993. The role of competition in successful establishment of selected prairie species, p. 193-198. In: R.G. Wickett, P.D. Lewis, A. Woodcliffe, and P. Pratt (eds.). Proc. 13th North Amer. Prairie Conf., Windsor, Ontario.

Jordan, W.R., R.L. Peters, and E.B. Allen. 1988. Ecological restoration as a strategy for conserving biological diversity. Environ. Mgt. 12:55-72.

Lentner, M. and T. Bishop. 1993. Experimental design and analysis. Valley Book Co., Blacksburg, Va.
Little, D.L. and D.L. Shaner. 1991. Absorption and translocation of the imidazolinone herbicides, $\mathrm{p}$. 53-70. In: D.L. Shaner and S.L. O'Connor (eds.). The imidazolinone herbicides. CRC Press, Boca Raton, Fla.

Martin, A.R., R.S. Moomaw, and K.P. Vogel. 1982. Warm-season grass establishment with atrazine. Agron. J. 74:916-920.

Masters, R.A. 1995. Establishment of big bluestem and sand bluestem cultivars with metolachlor and atrazine. Agron. J. 87:592-596.

Masters, R.A., S.J. Nissen, R.E. Gaussoin, D.D. Beran, and R.N. Stougaard. 1996. Imidazolinone herbicides improve restoration of Great Plains grasslands. Weed Technol. 10:392-403.

Schramm, P. 1978. The "do's" and "don'ts" of prairie restoration, p. 139-150. In: D.C. GlennLewin and R.Q. Landers (eds.). Proc. 5th Midwest Prairie Conf., Ames, Iowa.

Schramm, P. 1992. Prairie restoration: A twentyfive year perspective on establishment and management, p. 169-177. In: D.D. Smith and C.A. Jacobs (eds.). Proc. 12th North Amer. Prairie Conf., Cedar Falls, Iowa.

Shaner, D.L. and N.M. Mallipudi. 1991. Mechanisms of selectivity of the imidazolinone herbicides, $\mathrm{p}$. 91-102. In: D.L. Shaner, and S.L. O'Connor (eds.). The imidazolinone herbicides. CRCPress, Boca Raton, Fla.

Weaver, J.E. 1954. North American prairie. Johnsen Publishing Co., Lincoln, Nebr. 